\title{
Aristotelianism and the Soul in the Arabic Plotinus
}

\author{
Peter Adamson
}

It is common for historians of medieval thought to note that the influence of Aristotle on Islamic philosophy was tinged with Neoplatonism, thanks to a text known as the "Theology of Aristotle." It is now known that the "Theology" is in fact not a work of Aristotle's but rather a paraphrase of parts of Plotinus's Enneads. Certainly, the misattribution of this work to Aristotle facilitated the spread of Neoplatonism as an aspect of Islamic peripateticism, as represented by such authors as al-Kindī, al-Fārābī, and Ibn Sinnā (Avicenna). Some efforts have been made to assess its influence on particular philosophers, most notably Ibn Sīnā whose notes on the "Theology" have come down to us and who may have doubted its authenticity. ${ }^{1}$ Until recently the attention paid to the "Theology" itself has tended more towards philological than philosophical analysis, focusing in particular on possible sources of the text. ${ }^{2}$ Yet the differences between the original writings of Plotinus and its Arabic paraphrase are of considerable philosophic interest. In recent years research into the "Theology" has begun to pay more attention to the philosophical issues raised by the paraphrase. ${ }^{3}$ Here I hope to further this trend by suggesting that, although the au-

${ }^{1}$ For the Arabic text of Ibn Sīnā's notes, see 'Abdurrahman Badawī (ed.), Aristū 'inda 'l'Arab (Cairo, 1947), 37-74; French translation in George Vajda, "Les notes d'Avicenne sur la 'Théologie d'Aristote,'” Revue Thomiste, 51 (1951), 346-406. See also Jules Janssens, "Creation and Emanation in Ibn Sina," Documenti e studi sulla traduzione filosofica medievale, 8 (1997), 455-77, and Louis Gardet, "En l'honneur du millénaire d'Avicenne: L'importance d'un texte nouvellement traduit: les gloses d'Avicenna sur la pseudo Théologie d'Aristote," Revue Thomiste, 51 (1951), 333-45.

2 See Maroun Aouad, "La Théologie d'Aristote et autres textes du Plotinus Arabus," Dictionnaire des Philosophes Antiques, ed. Richard Goulet (Paris, 1989), 541-90, and F. W. Zimmermann, "The Origins of the So Called Theology of Aristotle," in Pseudo-Aristotle in the Middle Ages: The Theology and Other Texts, ed. Jill Kraye, W. F. Ryan, and C. B. Schmitt (London, 1986), 110-240.

${ }^{3}$ See Richard C. Taylor, "Aquinas, the Plotiniana Arabica and the Metaphysics of Being and Actuality," JHI, 59 (1998), 241-64, and Cristina D'Ancona Costa, "Il tema della 'docta ignorantia' nel neoplatonismo arabo. Un contributo all'analisi delle fonti di 'Teologia di Aristotele,' mimar II," in Concordia Discors: Studi offerti a Giovanni Santinello (Medioevo e Umanismo 
thor of this paraphrase was not Aristotle, his own thought was suffused with Aristotelianism.

First, we should note that the so-called "Theology of Aristotle" is itself only a part of an original, larger paraphrase of the Enneads. It is now usually thought that this paraphrase was authored by a member of al-Kindi's circle in ninth- century Baghdad. ${ }^{4}$ The original Arabic Plotinus has been preserved in three separate texts. The first is the "Theology" (hereafter Th.A) which is itself subdivided into a prologue, a series of "headings" (ru'üs), and ten chapters, each called a mimar, meaning "chapter" in Syriac. ${ }^{5}$ This is by far the longest of the three texts. We also have the so-called Letter on Divine Science, formerly attributed to al-Fārābi but shown by Kraus to belong to the Arabic Plotinus materials. ${ }^{6}$ Finally, there are the Sayings of the Greek Sage, a set of fragments collected from various sources by Rosenthal and Lewis which also paraphrases Plotinus in Arabic. ${ }^{7}$ As argued by F. W. Zimmermann, these three sources all derive originally from a lost, perhaps much more extensive, paraphrase of Plotinus. ${ }^{8}$ They are united both by writing style and philosophical content. I will call them, collectively, $A P$; and since I cannot here provide conclusive arguments as to the identity of their author, I will call him the Adaptor.

One of the major goals of al-Kindi and his circle seems to have been the synthesis of available Greek texts into a coherent philosophy. Thus al-Kindi himself produced doxographical works (for example, his Discourse on the Soul) and a survey of the Aristotelian corpus. ${ }^{9}$ If the Adaptor worked in such a milieu, he may well have been influenced by other philosophical sources in making a paraphrase of Plotinus. Zimmermann has suggested that such an influence is at

84) (Padua, 1993), 3-22; "Divine and Human Knowledge in the Plotiniana Arabica," in John L. Cleary (ed.), The Perennial Tradition of Neoplatonism (Leuven, 1997), 419-42, and Recherches sur le Liber de Causis (Paris, 1995).

${ }^{4}$ Supporting this are not only the arguments given by Zimmermann but also terminological and stylistic parallels between the Arabic Plotinus and other texts associated with Al-Kindī's circle: see Gerhard Endress, Proclus Arabus. Zwanzig Abschnitte aus der Institutio theologica in arabischer Übersetzung (Wiesbaden, 1973), 76-185, and 186ff.

${ }^{5}$ Though the use of this Syriac term has been taken by some as evidence for the identity of the author, such loan-words were not uncommon in the Arabic translation movement under the "Abbāsids. Thus Zimmermann (151) does not regard the term as evidence for a Syriac intermediary text.

${ }^{6}$ Paul Kraus, "Plotin chez les Arabes: Remarques sur un nouveau fragment de la paraphrase arabe des Ennéades," Bulletin de l'Institut d'Égypte, 23 (1941), 263-95.

${ }^{7}$ Most Arabic texts in 'Abdurrahman Badawī (ed.), Aflütīn 'inda 'l- 'Arab (Cairo, 1955); English translation by Geoffrey Lewis, based on his improved (but unpublished) edition of the Arabic text, in Plotini Opera II, Paul Henry and Hans-Rudolph Schwyzer (eds.), Plotini Opera (Paris, 1959). For Rosenthal's work on the "Greek sage" (al-shaikh al-yūnānī) see "Ash-Shayh al-Yūnānī and the Arabic Plotinus Source," Orientalia, 21 (1952), 461-92; 22 (1953), 370-400; 24 (1955), 42-66.

${ }^{8}$ Zimmermann, 112-13, 128-31.

${ }^{9}$ Arabic edition in al-Kindī, Rasā' $i l$ al-Kindī, ed. Muhammad 'Abdalhādī Abū Rīda (Cairo, 1950-53). For the Discourse on the Soul, see 272-80. 
work in mimar III, where the Adaptor may have drawn on Aristotle's De Anima in order to "reconcile" Plotinus with an Aristotelian theory of the soul as the entelechia of the body. ${ }^{10}$ Here I will examine the relationship of soul and body in $A P$ and expand on Zimmermann's thesis in an effort to show that the Adaptor was, in this respect at least, an Aristotelian interpreter of Plotinus. I will close by examining the relationship between $A P$ and a contemporaneous work, the paraphrase of the De Anima produced in al-Kindi's circle.

\section{Mìmar III and the Question of entelechia}

Students of Aristotle are familiar with his thesis that soul is the form of the body. In the De Anima Aristotle explains this further by claiming that the soul is the "perfection" or entelechia of the body (414a26). ${ }^{11}$ Of course there are various problems with the interpretation of this doctrine. Here the most pertinent of these problems is the question of whether the soul could exist separately from the body. Aristotle himself gives a qualified "no" to this question in De Anima II.1 (413a4-6), saying that at least a part of the soul would corrupt with the body, but the question was nevertheless debated in the later commentary tradition. Plotinus was critical of the Aristotelian doctrine of soul, since it seemed to imply that soul was either inseparable from body, or at least properly conceived of as the form of the body. For Plotinus the soul properly exists as its own hypostasis above body. For Plotinus the problem is to explain how soul can be "in" body or related to it at all, whereas for Aristotle the problem is to explain how, if at all, soul could exist separately from body.

Some passages in $A P$ give the impression that the Adaptor followed Plotinus in criticizing the notion that soul is the form of body. For example, he did not depart significantly from his source over the question of whether the soul is predicated of the body:

And the soul is also not in the body like a predicated [mahmūl] thing, and this is because the predicated thing is only an impression from the impressions of the bearer of predication [ $h \bar{a} m i l]$, for example color and figure: for these two are only impressions of the body [that is] the bearer for them, and the impressions do not separate from their bearers except through the corruption of their bearers. But the soul separates from the body without corrupting or dissolving through the dissolution of the body. (Th.A II.91 [B 43-44])

${ }^{10}$ Zimmermann, 117.

${ }^{1}$ Aristotle, On the Soul, tr. W. S. Hett (Cambridge, 1957). 
But neither is [soul] in the body as in a substratum [hupokeimenō], for what is in a substrate is an affection [pathos] of what it is in, like color and figure, and the soul is separable. (Enn IV.3.20) $)^{12}$

In both texts we see a theme which is repeated many times in Plotinus's works on the soul and in $A P$, namely that the soul cannot be essentially related to the body because it can survive being separated from body. The Adaptor repeats the point in the same section and adds a further argument for soul's independence:

The soul is not like a form in matter, and this is because the form does not separate from the matter except through corruption. The soul is not in the body like this, but rather it is separated from the body without corruption. Also, matter is before form, and the body is not before the soul, and this is because the soul is that which puts form in matter, that is, it is that which informs matter and that which gives body to matter. And if it is the soul that informs matter and gives body to it, then there is no doubt that it is not in the body like form in matter, because the cause is not in the effect like a predicated thing. Otherwise, the cause would be an impression for the effect, and this is extremely absurd, because the effect is the impression and the cause is the impressor. The cause is in the effect like the impressing agent, and the effect is in the cause like an impressed effect. (Th.A II.96-99 [B 44])

Neither is [soul] as form in matter, for the form in matter is inseparable, and the form [comes] later to matter already in being. But the soul makes the form in the matter, being other than the form. (Enn IV.3.20 [paralleling Th.A II.96-97])

Here the Adaptor adds, in an original passage, that soul cannot be the form of matter in the sense of an "impression" (athar) or effect of the matter, because then it would be the effect of the body instead of its cause. However, the Adaptor expands on Plotinus's claim that the soul "makes the form" in the body, saying twice that soul "informs" and "gives body to" matter (tusawwiru, tujissimu). Though these two verbs might associate the soul more closely with body than Plotinus does here, the overall impression of the passage is that the soul is not the form of the body, but the cause of that form.

${ }^{12}$ Enneads, vol. IV-VII, tr. A. H. Armstrong (Cambridge, 1984-88). All translations in the paper are my own, though I have consulted Lewis's translation of $A P$ and Armstrong's translation of Plotinus. When citing $A P$, I will give the section number from Lewis's translation, followed by the page number from Badawì's edition in brackets. 
The passage Zimmermann cites from mìmar III parallels part of Plotinus's critique of other views on the nature of the soul and follows the criticism of the Pythagorean theory that soul is the harmony of the body. Plotinus then addresses Aristotle's view:

One could examine how it is said of the soul that it is entelechia as follows: they say that the soul in the composite has the order of form regarding the ensouled body as matter, but is not the form of every body nor [of body] as body, but "of a natural organic [body] having life potentially." If, then, it is likened [to body] by being placed with it, as is the shape of the statue to bronze, then when the body was divided the soul would be partitioned at the same time, and when some part was cut off a part of soul would be with what was cut off. (Enn IV.7.8 )

Plotinus goes on to point out that in his view the entelechia theory of soul would make several activities of soul impossible, namely, sleep, reason's opposition to desire, and even thought in general. Then, he argues, there must be some aspect of soul, the "rational soul" (logizomenèn psuchen), which is separable from body. But even the desiring and growing functions of the soul would be separable, since we desire the non-bodily and the same soul can exist in different bodies at different times. He concludes that: "[the soul] does not have being (to einai) from being the form of something, but is a substance, not taking its being from its foundation in body, but being before becoming of this [body]" (Enn IV.7.85). Notice that the argument is based on showing that soul cannot be entelechia if it can be separated from the body, a strategy we already saw the Adaptor preserve in his paraphrase.

The Adaptor paraphrases the long passage above as follows:

If they say that the most excellent philosophers agree that the soul is the perfection [al-tamām] of the body, and perfection is not substance, so therefore the soul is not substance, because the perfection of the thing is only from the substance of the thing, then we say that we must examine their saying that the soul is some perfection, and with what meaning they call it entelechia [intalāshīa]. We say that the most excellent philosophers mentioned that the soul is in the body only as [ bimanzil: lit. "in the position of"] a form through which the body is ensouled, just as matter is body through form. Except that if the soul is the form of the body, then it is not a form to every body insofar as it is body, but rather is only form to a "body possessing life potentially." If the soul is a perfection according to this description [sifa], it is not of the domain of bodies. This is because, if it were form for the body like the form that is in a bronze idol, then if the body were divided and 
partitioned, [the soul] would also be divided and partitioned, and if one of the members of the body were cut off, then something of [the soul] would also be cut off. And this is not the case. Therefore the soul is not a form of perfection like the natural and artificial form, but rather is only a perfection because it is what perfects the body so that it comes to possess sensation and intellect. (Th.A III.67-70 [B 54])

Here the Adaptor agrees with Plotinus that soul is not in body as the form of the body itself, as what he elsewhere calls a "material form." (This, I take it, is the force of the phrase "natural and artifical form" in the last sentence.) Yet the Adaptor, unlike Plotinus, holds that in a sense the soul is the perfection or entelechia of the body. That this approval stems from the Adaptor's knowledge of Aristotle is clear. First, he says it is a view to which "the most excellent philosophers agree," replacing Plotinus's more non-committal "it is said" (legetai). Second, he retains the Greek word entelechia as a transliteration, which lends an air of authority to the view under discussion, and may imply that he knows the same word is used in Aristotle. Third, he faithfully retains the quotation from Aristotle that soul is the form of a "body possessing life potentially." The translation in Arabic here is very close to that in the Arabic paraphrase of the De Anima:

hiya sūrat al-jism dhā haya a bi-al-quwa ("it is the form of the body having life in potency"). (Th.A III.68)

al-nafs tamām li-jism tabì'i dhä hayā bi-al-quwa ("the soul is a perfection for the natural body having life in potency"). (De Anima, Paraphrase 215.5$)^{13}$

All this suggests that the Adaptor recognized Plotinus's quotation from Aristotle and, along with it, the Aristotelian provenance of the theory of entelechia.

In what sense, then, does the Adaptor recommend we understand Aristotle's definition of soul? He says that the soul is in fact the perfection or entelechia of body, but only because it is the source of the body's perfection. Hence he concludes this passage by saying that "the soul is not a form of perfection like the natural and artificial form, but rather is only a perfection because it is what perfects the body." This is a doctrine which seems to have been in the Adaptor's

${ }^{13}$ Rüdiger Arnzen, Aristoteles 'De Anima: eine verlorene spätantike Paraphrase in arabischer und persischer Überlieferung (Köln, 1998). All citations from the Arabic paraphrase of De Anima are from this text, with page number followed by line number. Notice that the elements of the $D e$ Anima definition not used here by the Adaptor, namely the words al-tamám and tab ' 'ं', are used nearby in III.67 and III.76. The original passage in the De Anima is at 412a27-28. 
mind in a passage we examined above (Th.A II.96-99), in which he said that the soul is not literally the form of the body, even though "the effect is in the cause," in other words the form for the body is in the soul. The Adaptor repeats the point when he comes to Plotinus's skeptical remark: "the reasoning soul, then, must be entelechia in another way than this, if one should use this name" (Enn IV.7. $8^{5}$ ). The paraphrase reads:

As for us, we say that there is no other soul besides this rational soul, which is in the body now, and it is that which the philosophers say is the entelechia of the body, even though they only mentioned that it is entelechia and a form of perfection in another way, different from the way which the materialists mention it. I mean that it is not perfection like the natural, effected perfection, but is rather active perfection (tamām $\left.f \bar{a}^{\prime} i l\right)$, that is, it makes (yaf'alu) perfection. With this meaning, they say that [soul] is the perfection of the natural, organic body which possesses the soul potentially. (Th.A III.75-76 [B 55]) $)^{14}$

Notice that the Adaptor here makes a distinction between two possible interpretations of Aristotle's theory. On the first, "materialist" theory, the soul is a natural perfection caused by something else. This theory would be vulnerable to the criticisms Plotinus presents in the parallel text. On the second theory, which the Adaptor adopts, soul is the source of perfection and as a result can be called a perfection in a higher sense. The result is that, where Plotinus is actually criticizing the doctrine of the De Anima, the Adaptor is only correcting what he sees as a possible misinterpretation of that doctrine.

Especially intriguing here is the strategy used by the Adaptor to define entelechia in a way that is not vulnerable to Plotinus's arguments. On the one hand he is arguing that a cause always shares a nature with its effect, so that the effect is "in" the cause. Both Aristotle and Plotinus would agree to this: Aristotle because the actuality of the cause must be similar to the actuality of the effect, and Plotinus because what participates in its cause cannot be wholly different from its source. But it seems to be the latter sense the Adaptor has in mind here: he is not thinking of Aristotelian physical causality, where a thing is similar to its efficient cause in its actuality, but of a hierarchical sort of causality. In other words the difference between form in soul and in body is not just that between agent and patient, but that between a higher and lower version of the same form. ${ }^{15}$

We can detect a further Neoplatonist tendency in the Adaptor's fluid use of the terms in question. Because the soul is the cause of form in the body, he holds that there is no sharp distinction to be made between soul and this form.

\footnotetext{
${ }^{14}$ Reading bi-al-quwa.

${ }^{15} \mathrm{I}$ am indebted to Prof. Richard Taylor for bringing to my attention the importance of this distinction here.
} 
Hence he can still agree with Aristotle that the body possesses soul potentially, and not form potentially. "Soul" is being treated here as a word with different levels of application, since the Adaptor considers it to be both a principle separable from the body, and hence distinct from the body, and a principle which is "in" and "informs" a particular body. The passages we have looked at so far indicate that the Adaptor is determined to hold on to both of these conceptions of soul, as both independent from and within body. This is perhaps unremarkable: the Adaptor does not depart greatly from Plotinus in this dual view of soul. After all, Plotinus does think of the soul as "fallen" into the body and as a result will also speak of soul being "in" the body in some sense. ${ }^{16}$ However, as we will see in the next section, the Adaptor associates soul with body more closely than does Plotinus, and even holds that the soul can in a sense become corporeal.

\section{The Soul's Relationship to the Body}

The attempt to detect Aristotelian influence on the Adaptor must take into account the extent to which Plotinus's own thought has absorbed Aristotelian elements. To the extent that the Adaptor just repeats these elements in his paraphrase, we cannot say that the Adaptor really departs from Plotinus because of the influence of, for example, the De Anima. On the other hand I would argue that these Aristotelian components of Plotinus's system facilitate the Adaptor's project of bringing Aristotle into the text of the Enneads. This is one reason to think that the Adaptor is not so much interested in revising Plotinus to accommodate his Aristotelian sources as he is in describing a single system of "ancient" thought which is drawn from a number of different sources. In this section such a strategy will emerge with regard to the relation of soul and body.

Here is an example of how the Adaptor paraphrases parts of Plotinus's text that have an Aristotelian ring to them:

If the body is simple and they do not say that the material is such as to have life through itself-for matter is not like that - but what is as form brings the life, then if they say that this form is a substance, then not the composite, but one of these [parts of the composite] will be the soul. (Enn IV.7.3)

We say that the simple body is composed from matter and form. It is impossible to say that the body possesses soul from the side of matter, because matter is not a quality for it. The body only possesses soul and life from the side of the form, because the body possesses taxis [taqis] and exposition through the soul, and the taxis and exposition are from

\footnotetext{
${ }^{16}$ See, for instance, Enn IV.8.1.
} 
the domain of the soul, because it belongs to the soul that there is taxis through it. (Th.A IX.35 [B 125])

Here Plotinus indirectly compares soul to form ("what is as form brings life"). This is the occasion for the Adaptor to say more explicitly that the body's reception of form is its reception of soul. Furthermore, the fact that the body is "composed from matter and form," put together with the close association of soul and form, seems to license the Aristotelian conclusion that a living body is a compound of soul and matter. The Adaptor comes closer to this conclusion in another, similar passage:

As for the soul, it is fixed and eternal in one state, not corrupting and not passing away. Through [the soul] the man becomes what he is, namely the true thing in which there is no falsehood, when it is subjoined to the body. The need of the soul for the body is like the need of form for matter, and like the need of the artisan for the instrument. Therefore the man is the soul, because he is what he is through the soul and becomes fixed and eternal through it, and through the body he becomes passing-away and corrupting. (Th.A IX.12-13 [B 122])

If this [body] is a part of us, the whole is not immortal, but if it is a tool, then it must, as given for some time, be of a nature to exist for that time. But [the other part] is the most important and is the man himself. If [the soul] is this, then it is to body as form to matter and as user to tool. (Enn IV.7.1)

Here Plotinus suggests that there is analogy between soul and form, and the Adaptor enlarges on this analogy by saying that, as form "needs" matter (presumably in order to be instantiated as a particular), so the soul "needs" the body, so that it can have something to use, like an instrument.

But the most crucial passage for the idea that a human is compounded of soul and body comes in a more complex discussion found in mimar $\mathrm{X}$. The parallel Greek text is Enn VI.7.4-5. Here Plotinus gives a detailed explanation of how "man" is emanated from nous to Soul and then into matter, arguing that "man" exists separately at each level. There are, then, three versions of man, and, as Plotinus says (Enn VI.7.6), the intellectual man (ho en nō anthropos) "illuminates the second [man], and this illuminates the third." In this part of the paraphrase the Adaptor understands Plotinus to be saying that the "third" or "lower" man is in effect the man of Aristotle's De Anima: a living thing composed from soul and body. His interpretation seems to be based to some extent on a passage where Plotinus supposes living things to be such composites: "but the living thing is [composed] from soul and body" (Enn VI.7.4, line 12). The 
Adaptor follows this with the paraphrase:

If the description [sifa] of man is what is composed from rational soul and body, then it is impossible that [the man] has a figure [shabah] of this description which is eternal. The man is only parts at the point of the assembly of the soul and the body. But rather, his quiddity [māhiyya] indicates the man being generated in the future, not the man who is called the intellectual and formal man. (Th.A X.56 [B 142])

But if that which is [composed] from rational soul and body is the logos of the man, how could it be an eternal hypostasis, with this logos of this sort of man being generated when body and soul are brought together? (Enn VI.7.4)

Here Plotinus is denying that "man" is in fact a compound of soul and body or more precisely, that the logos of that composite would be the logos of man. Rather, he wants to hold that the logos of man must be a higher principle separate from matter. He makes this clear a few lines later when he rejects Aristotle's idea that the logos would be a "this in a this" (tod'en tode). At this point, the Adaptor paraphrases as follows:

One must, when one wants to describe a material thing, describe it with its matter as well, and not describe it only with the word which made this thing. If one wants to describe an immaterial thing, then one may describe it only with the form. (Enn VI.7.4)

One must, even though one must speak of the logoi of enmattered forms as regarding matter [meta huless], yet grasp even more the logos which makes, for example, the man. (Th.A X.59 [B 143])

Here the Adaptor has changed the point of the passage. Plotinus argues that there is a place for discussion of matter when defining the material thing but that the $\log o s$ is primarily a transcendent principle. By contrast the Adaptor argues (as would Aristotle) that it is only immaterial things that are described or defined purely with reference to an immaterial form. ${ }^{17}$

With these slight shifts in the paraphrase the Adaptor has prepared the way for a more Aristotelian reading of Plotinus: that man, considered as a living, material thing, is the above-mentioned compound of body and soul. Thus we must describe man as a compound of both matter and form, or soul. He also recognizes the two "higher men" of Plotinus, the man of pure soul and the

${ }^{17}$ Compare Aristotle's comments at Metaphysics H.4, 1044a33-1044b11, where he stresses the need to mention the material cause in giving an account of generated substances. 
highest man in Intellect (Th.A X.78). But at the lowest level, he accepts Aristotle's conception of what "man" is. This comes out most strongly a bit later in the section:

If the soul is not man, then man must therefore be a word [kalama] other than the word of the soul. If this is the case, then what is it that keeps us from saying: the man is what is composed from both soul and body? (Th.A X. 64 [B 144])

Therefore the man must be a logos other than the soul. What prevents that the man is a composite, a soul in some logos? (Enn VI.7.5)

Here we see a more blatant change on the Adaptor's part, since the compound Plotinus is speaking of is composed of soul and logos, not body and soul. I would suggest that this change is due to the fact that throughout this part of mimar X the Adaptor is writing his paraphrase with Aristotle's theory of soul in the back of his mind. This thesis is further confirmed shortly thereafter:

This man is the one which the noble, divine Plato defined, except that he expanded his definition, and said that the man which uses the body and performs his activities through bodily instruments is just a soul using the body first. As for the noble, divine soul, it uses the body in a secondary way, that is, through the intermediary of the animal soul [alnafs al-haywāniyya]. (Th.A X.72 [B145])

This is that which Plato is defining, and he added "using a body" because it rides on the one which uses a body first, but the one [which uses the body] secondarily is more godlike. (Enn VI.7.5)

By the addition of the final phrase, "through the intermediary of the animal soul," the Adaptor implies that there is a soul at a lower level, the "animal" soul, which is compounded together with body to form the lowest man. If this is in fact his understanding of the human soul - that it exists as a material form in its lowest instantiation-then this allows us better to understand the treatment of entelechia in mimar III. For the lowest sort of soul turns out to be something very much like the Aristotelian soul, which is a perfection emanated from what is purely soul.

An important objection to such an interpretation of the Adaptor's view is that he often follows Plotinus in denying that soul is form. If he is really interested in defending the Aristotelian view, should not he insist that soul is, in some sense, form? We already saw one passage (Th.A IX.35) in which the Adaptor does associate soul closely with form. On the other hand other passages we 
looked at above seem to explicitly deny that soul is form in any sense, for example Th.A II.96: "The soul is not like a form in matter." Another, more extensive such passage can be found in mimar IX:

This is because, when the body remains alone, and the noble soul is not in it, it is incapable of remaining and of being a continuous unity, because it dissolves and is separated into the form and the matter, and it is only separated into these two because it is composed from them. The body only dissolves and separates, and fails to remain continuous in one state, due to the withdrawal of the soul, because the soul is that which composes [the body] from matter and form. So when it withdraws from it, it does not take long for [the body] to separate into the things from which it was composed. (Th.A IX.6-7)

[The body] is not [one], because it receives dissolution into shape [morphēn] and matter. (Enn IV.7.1)

It seems abundantly clear from this paraphrase that the soul is distinct from the form of the body, since, as the Adaptor says, the soul is the cause of that form. This might lead us to take somewhat less seriously the claim soon afterwards (IX.12) that the soul is to body "as form to matter." However, I think that such a rigorous distinction between form and soul is not what the Adaptor has in mind. Consider the following comment from another portion of $A P$, which has no Greek parallel text:

The third intelligible is the sensible, material form, which is intelligible accidentally, not through its essence. This is because the intellect is that which distinguishes [the form] from its subject in reasoning [amr al-mantiq]: it describes them as if they were subsistent in themselves [bi-dhätihā], distinct from their subjects. (DS 168 [B 189])

This passage shows that the Adaptor recognizes a form belonging to physical substances which is actually "sensible"-presumably what he has in mind here is something like the shape of a body or any other form which accounts for its physical characteristics. It is quite likely that he also means this sort of form in Th.A IX.6-7, just quoted above: this is the form of the body, the "natural and artificial form" we saw mentioned at Th.A III.70. For here the Greek word morphe has been translated as "form," so that the Adaptor might not mean, say, the substantial form of the thing ("humanity" in the case of a human) but only its physical form or "shape." Then his point is that soul is what compounds a body out of matter and "sensible or material" forms. But the soul may still in some sense be the "form" of the body as is implied in other passages. This is espe- 
cially so given that, as we have seen, the Adaptor conceives the lowest instantiation of the soul along Aristotelian lines, that is, as entelechia and as that which combines with body to make man.

We can be more clear about the sense in which the soul is the form of body, or becomes bodily, by focusing on the Adaptor's treatment of different parts or faculties of the soul. In the first mimar we read:

As for the soul of man, its essence has three parts: vegetative, animal, and rational, and it is separated from the body upon its collapse and dissolution, except that the pure, clean soul which has not been dirtied and has not been sullied by the squalors of the body, when it separates from the sensible world, will then return to those substances quickly and without hesitating. (Enn IV.7.14)

If it is said that the soul of man, being tripartate (trimerēe, will be destroyed by its composition, we also will say that the pure [souls], when set free, shed that which was plastered to them in their generation. (Th.A I.14 [B 20])

There is an obvious addition here which specifies what the three parts of this "tripartate" soul would be. Not only does Plotinus not say what the three parts are but if he had, he would presumably not have given the list found in Th.A, for he is doubtless thinking of the tripartate soul in the Republic. The Adaptor's division seems rather to be drawn from Aristotle. At the outset of the Arabic De Anima paraphrase, for example, we find a similar division of soul into "the growth soul, the sensitive soul, and the rational soul" (185.2-3). This technical division of soul is yet another Aristotelian aspect of the Adaptor's doctrine.

We have already seen that the Adaptor is concerned both to agree with Plotinus that the soul can exist independently of body and to retain the close connection between soul and body found in the De Anima. The division of the soul into parts or faculties gives him a way to account for this twofold nature of soul. He holds that the soul is "bodily" or "in" body with regards to some of its faculties, in particular those of the nutritive and animal or sensitive soul. But with regard to the "rational" soul, the soul transcends body and survives the corruption of the body. Thus we find statements like the following:

These faculties are not like the sensory faculties, but they are according to another kind. This is because the sensory faculties are parts after these faculties, and therefore they come to be more corporeal [ashaddan tujassuman]. (Th.A II.67 [B 40]) 
Similarly, in mimar II there is a lengthy discussion of how the soul is "divided" in the body. Here the Adaptor goes beyond the parallel text in Plotinus to say that the soul is divided in place by exercizing its different functions in different parts of the body. However, he insists that this division is an accident which comes to the soul as a result of its residing in body, as opposed to an essential division. The passage is largely independent from the original Greek:

It must be known whether the soul is divided (tatajazza 'u), or not divided, and if it is divided, then is it divided through its essence, or through an accident (bi-'aradin)? And likewise, if it is not divided then is it not divided through its essence, or through an accident? We say that the soul is divided through an accident, and this is because, when it is in the body, then it admits of division through the division of the body, as you say that the thinking part is other than the brute (bahimin) part, and its sensual part is other than its wrathful part. By "part" we only mean a part of the body in which is the thinking faculty of the soul, and the part in which is the sensual faculty, and the part in which is the wrathful faculty. For the soul only admits division through an accident, not through its essence, that is, through the part of the body which it is in. But as for [the soul] in itself, it does not admit of division at all. When we say that the soul is not divided, we only say this generally and essentially, and when we say that the soul admits division, we only say this secondarily and accidentally, because [the soul] is only divided when it comes into the bodies. (Th.A II.58-61 [B 38-39]) ${ }^{18}$

Shortly afterwards we have a passage which is completely independent from the Greek:

The faculty of the soul is of two sorts: one of them is divided through the parts of the body like the senses, and the other is not divided through the parts of the body, like the augmentative faculty and the appetetive faculty, for they are spread through the whole body of the plant. The faculties divided through the parts of the body are brought together by another faculty, more lasting, more noble, and higher than them. (Th.A II.70 [B 40])

Taking these lines together with II.58-61, we see the Adaptor adding a number of important points to Plotinus's discussion of whether soul can become divided:

${ }^{18}$ I read the sense of the Arabic differently from Lewis: the Adaptor is asking whether the division of the soul is essential or accidental, not whether the soul is an accident. Lewis also translates tatajazza' $u$ as "particularized," which is somewhat misleading. 
(1) The division of soul is accidental, not essential.

(2) The division of soul in body is tied to its division into numerous faculties or "powers" (quwan).

(3) Part of the soul, which is more "lasting and noble," remains undivided and presumably above body.

This last point refers, it seems, to the "thinking" or "rational" soul, which is superior to the bodily aspects of soul. The Adaptor makes this distinction here and elsewhere with reference to the "brute" soul (al-nafs al-bahimiyya). This distinction parallels one made by Plotinus himself, between the rational soul and the "irrational soul" (alogos psuchē). ${ }^{19}$ Mentions of the brute soul in $A P$ often make the point that this lower soul is affected by and existent in body, in a way that the rational soul is not. For example, at Th.A VI.50 he says: "this is because some impressions fall on the brute soul, and it receives them, to the exclusion of the rational soul." One of these impressions, needless to say, is the accidental "division" attributed to the soul in mimar II. There is an ontological distinction, then, between different levels of the soul, which corresponds to the difference between the faculties of the soul. ${ }^{20}$ It seems likely that the Adaptor thought of the lower or "brute" soul chiefly in terms of doctrines taken from Aristotle. After all, much of De Anima, and especially much of the Arabic paraphrase of De Anima, is taken up by discussions of nutrition, motion, and sensation, all faculties that for the Adaptor would be associated with the brute soul. If he holds, with Plotinus, that there is also a higher, non-bodily sort of faculty associated with the human soul, then this need not be seen as a rejection of Aristotelian doctrine. For support of this notion in Aristotle one need only to turn to the beginning of the second book of the De Anima: "regarding the intellect and the theoretical powers, it is not yet clear [what we should say], but this seems to be another kind of soul, [differing] just as the eternal from the corruptible" (413b24-27). As we will see below, the Arabic paraphrase of the De Anima reads the third book of the text in a Plotinian light. Indeed, one issue we will need to address is that of the mutual influence that these two Arabic paraphrases had upon each other.

It is clear, at any rate, that the Adaptor's division of the soul into "rational" and "brute" soul further facilitated his doctrine that the soul is closely tied to body. Other passages on this topic in $A P$ show that these close ties can in the Adaptor's view lead to a complete "corporealization" of the soul, or a complete

${ }^{19}$ See Th.A VI.26-29, and the parallel mention of the alogos psuchei $i$ at Enn IV.4.40.25; also Th.A VI.49-50, with the Greek phrase used at Enn IV.4.43 lines 8 and 12.

${ }^{20}$ See also Th.A IX.64 (B 129): "We say that the proof that the soul is in this world through some of its faculties and is in the intellectual world through the rest of its faculties is justice, righteousness, and the other excellences." This passage, incidentally, makes a completely different point from that made in the parallel Greek text, which argues that virtue exists discursively in soul, and non-discursively in nous. 
fall of the soul into the material realm. Most passages of this kind tie this fall to ethical concerns. The Adaptor first argues that the higher soul is immune to ethical lapses:

We must not ascribe any of the acts to the intellectual soul except the acts which the soul does intellectually, namely its essential, commendable, noble acts. As for the base, blameworthy acts, they must not be related to the intellectual soul, but rather only related to the brute soul (al-nafs al-bahimiyya), because they are impressions that fall on this soul, not on the intellectual soul. (Th.A VIII.108 [B 109])

These alone must be called acts of soul, that which [it does] noetically and which is proper to it (hosa oikothen); the worse is from something else and belongs to a soul of such a kind. (Enn V.1.3)

Note that here the Adaptor adds the distinction we have been discussing, between the brute and intellectual soul. Elsewhere he goes even further, suggesting that these "base acts" can lead the soul to fall entirely down to the level of the material. Neither of the following examples have Greek parallels:

When [the soul] continues the vision of the intellect, it acquires from [intellect] the noble excellences. But if it is unmindful and turns to sense and occupies itself with this, then the intellect does not emanate any of the excellences on it, and it comes to be like one of the sensory, base things. (Th.A IX.68 [B 129])

The soul only makes these impressions upon ( inda) its desire for the vilest, lowest thing. When it desires it [the soul] makes an impression in it, and comes to be, along with ('inda) sense, more vile than any other. ${ }^{21}$ (Th.A X.20 [B 136])

It is hard to imagine Plotinus saying that the soul could ever descend to such a debased state. It seems that the Adaptor uses the stronger rhetoric in order to emphasize the disastrous moral consequences that follow when the soul is turned away from the higher world. He often adds a moral dimension to his source, for example in this passage which reinforces the claims quoted above:

${ }^{21}$ Reading akhiss with Lewis. Badawī's reading, which makes no sense in this context, would have "more beautiful than every beauty." 
It is likewise for the rational soul: everything which it acquires from the pure, bright intellect is something noble and excellent as well, and everything it acquires from sense is something base and vile. (DS 46 [B 170])

[B] ut soul is from intellect, taking other things, among which are these, from matter. (Enn V.9.13)

We cannot here enter into a discussion of ethical views throughout $A P$. For our purposes, it suffices to point out that the Adaptor's ethical doctrines are reinforced by the notion that the soul can fall utterly into body, becoming, so to speak, corporeal. This notion was, perhaps, more plausible to the Adaptor than to Plotinus, owing to the Adaptor's use of a more Aristotelian conception of soul throughout his paraphrase.

\section{$A P$ and the Arabic paraphrase of the De Anima}

So far we have concentrated our attention on the ways in which the Adaptor's handling of Plotinus was influenced by Aristotle, and in particular by the doctrines of the De Anima, but the reverse is also true: an Arabic paraphrase of the De Anima which originated in al-Kindī's circle seems to have been written under the influence of Plotinian doctrine. ${ }^{22}$ In his volume on the De Anima paraphrase Rüdiger Arnzen provides several parallels that would indicate this is the case:

1. The De Anima paraphrase says that the soul always knows (201.15), as opposed to going from potency to act in intellection. Arnzen draws a parallel between this and DS 237 ("it is impossible that the intellect is sometimes knowing and sometimes ignorant"), which directly parallels Enn V.9.2. ${ }^{23}$

2. In the De Anima paraphrase, we find a passage (203.9-15) which shows that the soul is not a body, because it does not have parts, even though the presence of different sense faculties in different organs might suggest that it does. This parallels a passage in Plotinus (Enn IV.3.3) where he says that neither the world soul nor the individual soul are divided into parts because of sensation. ${ }^{24}$ The Greek passage is not paraphrased in AP (though later portions of Enn IV.3 are). Compare, however, the treatment of the division of soul in mìmar II (Th.A II.58ff.) discussed above.

3. The paraphrase of De Anima says that the soul is the perfection (tamäm) of body, but a separable perfection, like the pilot of a ship. Here the non-sepa-

${ }^{22}$ See the linguistic parallels between this paraphrase and $A P$, as well as other products of al-Kindī's circle, provided by Arnzen, 108-14; also Endress, 189.

${ }^{23}$ Arnzen, 115.

${ }^{24}$ Arnzen, 115-17. 
rable perfection is compared to the heat that is the perfection of fire. Arnzen finds a parallel for this at Enn V.4.2: "There is the actuality [energeia] that is of the substance, and another actuality that is from the substance." Plotinus also uses fire as an example for these sorts of actuality. This passage is paralleled at DS $173-77 .^{25}$

4. The distinction found in Th.A III between entelechia as perfection and as that which is a cause of perfection (see above) is also found in the De Anima paraphrase: "Perfection [al-tamām] is of two kinds, one that the thing is the perfection itself [bi-'aynihi], for example the heat of fire, for the fire is perfected through it and thus is fire, and the other that the thing is making the perfection, for example the sailor is the perfection of the ship" (217.9-12). ${ }^{26}$ Arnzen remarks that the writer of the De Anima paraphrase here seems to have been motivated not so much by the desire to interpret Aristotle in a Plotinian light, or to defend Aristotle from Plotinus, as he was to "attain a synthesis of both philosophical systems." ${ }^{27}$

5. Finally, Arnzen sees the writer of the De Anima paraphrase as trying to steer a middle course between Aristotle and Plotinus, when he says that soul is "not in the body like a material form" (ka-al-sura al-hayülāniyya) (315.11). On the one hand, says Arnzen, this accepts Plotinus's point that a material form cannot separate from the body, whereas soul can. On the other, he does not go so far as to reject the entire idea that the soul is form or entelechia, because he refers only to a "material form." Here one might think of the similar strategy we saw above in $A P$, where the Adaptor seemed to deny only that the soul is the form of the body in the sense of a physical shape.

To this list we can add further thematic parallels between the De Anima paraphrase and $A P$. One of the most striking is the distinction made in the $D e$ Anima paraphrase between the rational soul (al-nafs al-nätiqah) and lower parts of the soul. Whereas the latter are destroyed with the body (319.9-10), the rational soul "is not mixed with anything material or bodily, and is not body" (189.14-15). As a result of this, "there is no doubt that the rational soul is eternal, does not corrupt, and does not perish" (311.5-6). Furthermore, the body hinders the functioning of the intellectual soul (319.3-4) and is the cause of the soul's "forgetfulness" (327.5). While Aristotle's text, especially De Anima III.5, does of course provide support for the idea that intellect (nous) is eternal (430a23), the identification of rational soul as an eternal faculty of the human soul does not seem to come from Aristotle. The difference between these two

${ }^{25}$ Arnzen, 117. Note that in the De Anima paraphrase, as in AP, tamäm translates entelechia, not energeia (e.g. at De Anima paraphrase 215.12, translating directly De Anima $412 \mathrm{~b} 5$ ). Still, the notions of perfection and actuality seem close enough in all of these texts to license the parallel drawn by Arnzen.

${ }^{26}$ Arnzen, 118.

${ }^{27}$ Arnzen, 119. 
positions - an eternal nous as opposed to an eternal rational soul-is underscored by the De Anima paraphrase itself. For it argues separately that the intellect ( ' $a q l$ ) is eternal (309.16-17) and that the rational soul is eternal (311.5-6), and indeed it seems to use the first point as evidence for the second. While it would be rash to say that this doctrine is derived from Plotinus, given the complexities of the tradition of commentary on the De Anima, the notion of a separable and rational soul does provide an important philosophical parallel to $A P$. As we saw above, the Adaptor treats the lower or brute soul in a rather Aristotelian way, and emphasizes its connection to body in contrast to the rational soul. The author of the De Anima paraphrase, conversely, departs from his own source text to treat the rational soul as a transcendent, non-bodily principle in line with the Plotinian soul. Whatever the sources used by the two authors, they take an identical position on the immortality of the soul: the lower, bodily faculties are destroyed with the body, but the part of soul that is related to the intellect is eternal.

This is only one of a number of doctrinal agreements between $A P$ and the De Anima paraphrase. We might further add the insistence in the De Anima paraphrase on the idea that the soul is a "simple substance" (jawhar mabsüt). ${ }^{28}$ The simplicity of substance is crucial in $A P$, since the Adaptor argues that the soul's simplicity means that it cannot be destroyed (for example, Th.A IX.4). The eternity and simplicity of soul are likewise linked in the De Anima paraphrase (196.5-6). Both paraphrases also use the simplicity of soul as evidence that the soul is immaterial (see Th.A IX.13, De Anima paraphrase 203.16-18). While these parallels cannot demonstrate direct textual influence, they increase our sense of the similarity of the views set forth in the two texts. It might be added here that this rather Neoplatonized conception of the soul as a simple substance seems to have carried considerable weight in al-Kindī's circle as an interpretation of the De Anima. Thus al-Kindi's Discourse on the Soul begins by asserting that the soul "is a simple substance," and another work by al-Kind $\mathbf{1}$ summarizes Aristotle's doctrine on the soul by saying that it "is a simple substance whose acts manifest from the bodies." 29

Another parallel between the De Anima paraphrase and $A P$ can be found in their respective critiques of previous views on the soul. In both Greek source texts there are extended discussions showing the falsity of psychologies from the Greek tradition. Aristotle criticizes materialist views of the soul in De Anima I.2, views on the soul's motion in I.3, and the Pythagorean view of soul as harmony of the body in I.4. Plotinus follows a similar procedure, arguing against those who describe soul as material, as harmony, and as entelechia. We have already seen how the Adaptor was influenced by Aristotle in his paraphrase of

\footnotetext{
${ }^{28}$ De Anima paraphrase 202, 212, 306. For the doctrine that the soul is simple, see also 196. The paraphrase refers to the soul as substance also at $180,214,222,314$, and 320 .

${ }^{29}$ Al-Kindī, Discourse on the Soul 280.8, Brief Statement on the Soul 281.5-6.
} 
the latter point. The Arabic paraphrase of the De Anima departs considerably from its source in its criticisms of previous views, depending partially on arguments taken from John Philoponus..$^{30}$ As a result, its rejection of the materialist view of soul is more explicit than Aristotle's and is based on different arguments. Indeed, Aristotle does not concentrate on proving the immateriality of soul at all, contenting himself with the observation that "all define the soul by three things, motion, sensation, and immateriality" (405b11-12). While one might argue that the emphasis on this point in the De Anima paraphrase is inspired by Plotinus's text, I find no striking parallel between the arguments against materialism in the two texts.

We do find a parallel argument, however, when we come to the question of whether the soul is the harmony of the body. Aristotle argues against this (De Anima I.4) by saying that the harmony of body is just health and that soul can be a harmony in the sense neither of spatial proportion nor of a ratio of blended consituents. In the De Anima paraphrase we find a different argument:

If the soul is like this, that is, a shape which comes about from the formation [ $\left.t^{\prime} l i \bar{f}\right]$ of the bodies, we say: it would therefore be necessary that there are in us many souls, because the formation of every one of the members of the body is different from the formation of every other [member]. If this were the case, then it would be necessary that there are many souls in us, and this is absurd [bätil]. (De Anima paraphrase 211.1-3)

Compare this to the following passage in the Enneads:

And for each part, which is mixed differently, there would be a different soul, so that there would be many [souls]. (Enn IV.7. $\left.8^{4}\right)$

The parallel with $A P$ is even stronger:

Also, if the harmony [itiläf-same root as ta'li $f$ above] only happens from the harmony of bodies, and the harmony is soul, and the union of every one of the members of the body is different from the union of every other [member], you are harmonizing many souls in the body, and this is very repugnant [shanī $\left.{ }^{\top}\right]$. (Th.A III.61 [B 53])

The similarity of the phrasing in the two Arabic texts makes it extremely unlikely that both were drawing independently on the text of the Enneads. Given that the passage in Th.A is itself a paraphrase of Plotinus, it seems clear that in this case the author of the De Anima paraphrase was drawing on Th.A.

${ }^{30}$ See Arnzen's notes, $364 \mathrm{ff}$. 
This passage, then, should be added to one discussed by Arnzen, in which the De Anima paraphrase draws on the beginning of Th.A to point out that the body holds the soul back from returning to "its world" (Th.A I.1 and De Anima paraphrase 319.5-6) ${ }^{31}$ These parallels prove that Th.A was a source for the Aristotelian paraphrase. Arnzen provides a parallel which may show that the reverse is also true:

Sense is not from the realm of the intellect, and this is because sense is corrupted by the powerful sensible which is beyond proportion, and [then] it cannot perceive the weak sensible which is deficient of proportion. But the intellect is not like this, because it perceives the strong intelligible, and what is weak among the intelligibles is not thereby hidden from it, but rather it is more able to [perceive] it ... because the greater the power of the intelligible, and the more noble its substance is, the more the intellect increases in light and knowledge and endurance. (De Anima paraphrase 309.3-11)

The longer vision gazes at the sensible thing, the more the sensible thing harms it, until it brings it to be outside sense; that is, [vision] does not sense the thing. But as for intellectual vision, it is the opposite of that. I mean that, the longer its gaze upon the intelligible, the more is its knowledge and the more it deserves to be intellect. (Th.A VIII.164)

There is no parallel in the Enneads for this passage. Rather, as in the section from the De Anima paraphrase, the Adaptor's thought here depends closely on Aristotle:

For sensation is not able to perceive after a violent (sphodra) sensation ... but the intellect, whenever it thinks the powerful (sphodra) intelligible, does not think the less intelligible less, but rather more. (De Anima 429a31-429b4)

While there can be no doubt that the passage in Th.A derives ultimately from the Greek text of the De Anima, I think it is less clear that this derivation was by way of the Arabic De Anima paraphrase. Arnzen concludes that the Adaptor was using the Arabic text and not the Greek on the basis of the similarity between the final phrases in the passages cited. However, the parallel here is not as strong as that in the case of the argument about harmony cited above. The only word used in both passages is "knowledge" ( $m a$ 'rifa), though Arnzen is right to point out the structural similarity of the phrasing. This seems insuffi-

\footnotetext{
${ }^{31}$ Arnzen, 121-22.
} 
cient evidence for the claim that Th.A uses the De Anima paraphrase, and not just the De Anima itself, as a textual source. ${ }^{32}$

The relation of $A P$ to this other Arabic paraphrase, then, seems to be as follows. We can be sure that the author of the De Anima paraphrase had access to Th.A when he composed his own text. It is possible, but, I think, still uncertain that the Adaptor relied upon the Arabic version of the De Anima. ${ }^{33}$ If he did, then Arnzen is right to point out that the two paraphrases must have been composed contemporaneously, that both were parts of the translation project in al-Kindī's circle. ${ }^{34}$ As he also says, the authors of the two paraphrases would have referred to each other's texts as they composed their own. The other possibility is that the Adaptor referred to the original Greek of the De Anima while composing $A P$ and that the De Anima paraphrase was produced later. In either case two important conclusions emerge from our textual comparison. First, it adds to our sense of $A P$ as part of a larger translation project. Second, it is apparent that both paraphrases were intended not only as translations but also as texts that would show the agreement of their own sources with other Greek works. Thus the author of the De Anima paraphrase wove Plotinian ideas into the fabric of an Aristotelian source. And as we have seen, the Adaptor used Aristotle's De Anima, perhaps in its original Greek version, as a tool for interpreting Plotinus.

University of Notre Dame.

${ }^{32}$ See also Arnzen, 123 n. 59, which rejects a different argument by Zimmermann for the reliance of $A P$ upon the De Anima paraphrase.

${ }^{33}$ Since the parallels discussed above deal only with Th.A and not $G S$ or $D S$, it remains unclear whether the author of the De Anima paraphrase read only Th.A or some more complete version of the Arabic Plotinus. (See, however, Arnzen 121, which argues that one parallel between the texts shows the author of the De Anima paraphrase using an earlier text of the Arabic Plotinus not split up into $T h . A, G S$ and $D S$.) But given the overwhelming evidence that all parts of $A P$ were written by a single author as one original text (see footnotes 4 and 8 above), it seems safe to assume that if Th.A was influenced by the De Anima paraphrase, then the same goes for $A P$ as a whole.

${ }^{34}$ See Arnzen, 123. 